\title{
THE REALITY OF APPLYING DECISION SUPPORT SYSTEM SUCCESS FACTORS IN THE UNIVERSITY EDUCATION ENVIRONMENT: CASE STUDY APPLIED TO TAIBAH UNIVERSITY
}

\author{
Dr. Ahmad Abdelqader Abuseeni and Dr. Husam Alfahl \\ Department of Management Information Systems, \\ College of Business Administration, Taibah University
}

\begin{abstract}
The development of the field of information technology has led to systems, tools, and techniques that aim to support managers in making decisions, reflected in improved business performance at all managerial levels in the organization, particularly arising from its contribution to the process of continual improvement of employees. This study highlights the reality of applying the success factors of design support systems in the university education environment, through a case study of Taibah University in Saudi Arabia. First, a model was built based on the decision support system success factors that were identified by previous studies. These factors are then tested to determine which applied in the university educational environment, from the point of view of faculty and staff. Data were collected using a measurement questionnaire, and subjected to statistical analysis using SPSS and structural equation modeling using AMOS. The results suggested a number of conclusions, the most important of which was the validity of the relationship between the two dimensions of the research. The paper concludes with the presentation of a set of recommendations, providing all the requirements for the implementation decision support systems in the field work of the university.
\end{abstract}

Key words: decision support systems (DSS); human resource information systems (HRIS); university education environment (UEE).

Cite this Article: Dr. Ahmad Abdelqader Abuseeni and Dr. Husam Alfahl, The Reality of Applying Decision Support System Success Factors in the University Education Environment: Case Study Applied to Taibah University. International Journal of Information Technology \& Management Information System 9(1), 2018, pp. 01-20.

http://iaeme.com/Home/issue/IJITMIS?Volume=9\&Issue=1 


\section{INTRODUCTION}

The information age, with its explosion of knowledge and flow of information, has seen businesses seek to improve or maintain their competitiveness in the increasingly challenging global marketplace. Information systems are regularly used as a tool to advance customer service, shorten cycle times, and reduce costs(Hitt, Wu, \& Zhou, 2002). Brockbank (1999) recommended human resources (HR) become a strategic partner, and emphasized the need for human resource information systems (HRIS).HRIS supports planning, administration, decision-making, and control of human resource related issues. In addition, it can be utilized to enhance employees selection and placement, payroll, pension, reimbursement management, training projections, career pathing, equity monitoring, and productivity evaluation. Such information systems increase administrative efficiency and produce reports capable of improving decision-making (DeSanctis, 1986).

The current study was conducted to focus on the reality of Decision Support Systems (DSS) success factors in the University Education Environment (UEE). A model was built based on the DSS success factors identified by (Mabrouk, 2012)and these factors include physical resources, technical resources, HR, organizational facilities, and senior management awareness. The next section presents a literature review followed by sections on the research problem, the importance of the research, the research objectives, hypotheses, and model. The methodology is explained in the following section, including subsections on exploratory factor analysis (EFA), data collection, analysis, reliability and validity analysis, convergent validity analysis, discrimination validity analysis, and confirmatory factor analysis (CFA). The following section describes frequent analysis, and the final section presents a discussion and conclusions with some suggestions for future work.

\section{LITERATURE REVIEW}

Al Hassani (2013)studied the both direct and indirect impact of DSS on information quality and effective decision-making in the Ministry of Civil Service of the Sultanate of Oman. In his study, 78 employees were surved using a questioner. In addition, simple and multiregression analysis, and path analysis were preforred to analiyze the collected data. The results shows that there is a significant impact for the dimensions of the information quality on the effective decision-making(Al Hassani, 2013). The study also confirm that, in such setting, DSS had a significant impact on the effectiveness of decision-making and information quality.

Ramadan (2009)investigated the impact of DSS on developing the performance of the Ministry of Education, Gaza. 230 employees who are working in the supervisory positions were surveyd using a questionnaire. The study found that there are significant differences the on the impact of DSS on the development of performance attributable based on the variables of sex, qualifications,specialization, and region of the respondents.

Al-Mobaideen, Allahawiah, and Basioni (2013)examined the main factors influencing the successful adoption of DSS in the Aqaba Special Economic Zone Authority, Jordan, including system characteristics (perceived ease of use and perceived usefulness), technical aspects (information technology infrastructure and information systems interoperability), and organizational aspects (top management support, management style, and organizational structure). The findings indicated that IT infrastructure has a positive and significant effect on the successful adoption of HRIS, but there is no significant effect from perceived usefulness and ease of use, top management support and IEC on the successful adoption of HRIS. Finally, the results indicated that there were no significant statistical differences arising from 
demographic characteristics on HRIS adoption. The researchers proposed a set of recommendations for better adoption of HRIS in the Aqaba Special Economic Zone.

Guimares, Igbaria, and Lu (1992)investigated the determinants of DSS success. A multivariate model was developed and tested using multiple regression hierarchical analysis and data analyses, which indicated that DSS success, as measured by DSS satisfaction and perceived benefits, depends on several factors, including user experience with DSS, user involvement, user training, top management support, information sources, level of managerial activity, task structure and difficulty, and interdependence.

Sanders and Courtney (1985)explored several variables in the organizational environment thought to influence the success of DSS. Further support was given to the importance of factors that have historically been shown to affect transaction processing systems and management information systems; for example, top management support has consistently been shown to influence the implementation of computer-based systems, and this study reaffirmed those findings. They also provided further evidence regarding the role of training in DSS development. Further, length of use was shown to be a critical factor contributing to DSS satisfaction.

Mabrouk (2012) defined DSS success factors in terms of the relevance of the available information, the adequacy of the available information, the appropriateness of the models and reports used, with success factors including the availability of appropriate physical, technical, and human resources, and the degree of organizational facilities and senior management awareness and support. In our study, as noted in the introduction, we adopt the factors defined in Mabrouk (2012).

\section{RESEARCH PROBLEM}

Based on the introduction, the research problem can be expressed by asking the following question: what are the design support system factors that apply in the UEE? Further, what are most influential design support system factors that apply in the UEE?

\section{The Importance of the Research}

This research is of both academic and practical importance. The research questions prompt answers that add to the understanding of the theoretical framework for definitions of DSS and associated success factors. In practical terms, this research adds to evidence on DSS success factors that apply to the UEE.

\section{Research Objectives}

The objectives of the research are:

- To determine via respondent answers the levels of use of DSS in the UEE.

- To determine the nature of the most influential DSS factors in the UEE.

\section{Research Hypotheses}

The following research hypotheses were formulated:

- There is a significant difference in the extent of application of DSS factors.

- Respondent answers vary in terms of the most influential DSS factors applied in the UEE.

\section{RESEARCH MODEL}

This research focuses on the reality of applying DSS success factors in the UEE. The model was built based on the five DSS success factors defined by Mabrouk (2012)(see Figure 1): 
- Physical resources: sufficient computers with appropriate capabilities and a variety of storage facilities suited to the needs of the work; a network with suitable characteristics, capabilities and speed to connect devices; a specialized technical support and maintenance team to update the hardware and software periodically.

- Technical resources: the quality of the programs used, in terms of being current, easy to learn, suitable for the requirements of the work, and compatible with the devices and the network used; available programs must cover all required activities, with continuous evaluation by users.

- HR: specialized highly qualified IT personnel, available to respond to and capable of understanding employee inquiries and problems.

- Organizational facilities: facilitating access to appropriate information regarding work, as well as the necessary financial support for the use of DSS; the administration should take note of the opinions and suggestions of the employees and provide training programs on the use of DSS, as well the necessary requirements to improve the use of DSS. The organizational structure should be such that officials can evaluate performance.

- Senior management awareness: the extent to which management relies on DSS in decisionmaking, and the extent to which managers encourage staff to use DSS, support training courses, provide the necessary hardware and software, and support the efforts of staff to design and develop DSS. The administration should be concerned with making the process of design and development of DSS part of the comprehensive organizational development process, and be well aware of the importance of DSS.

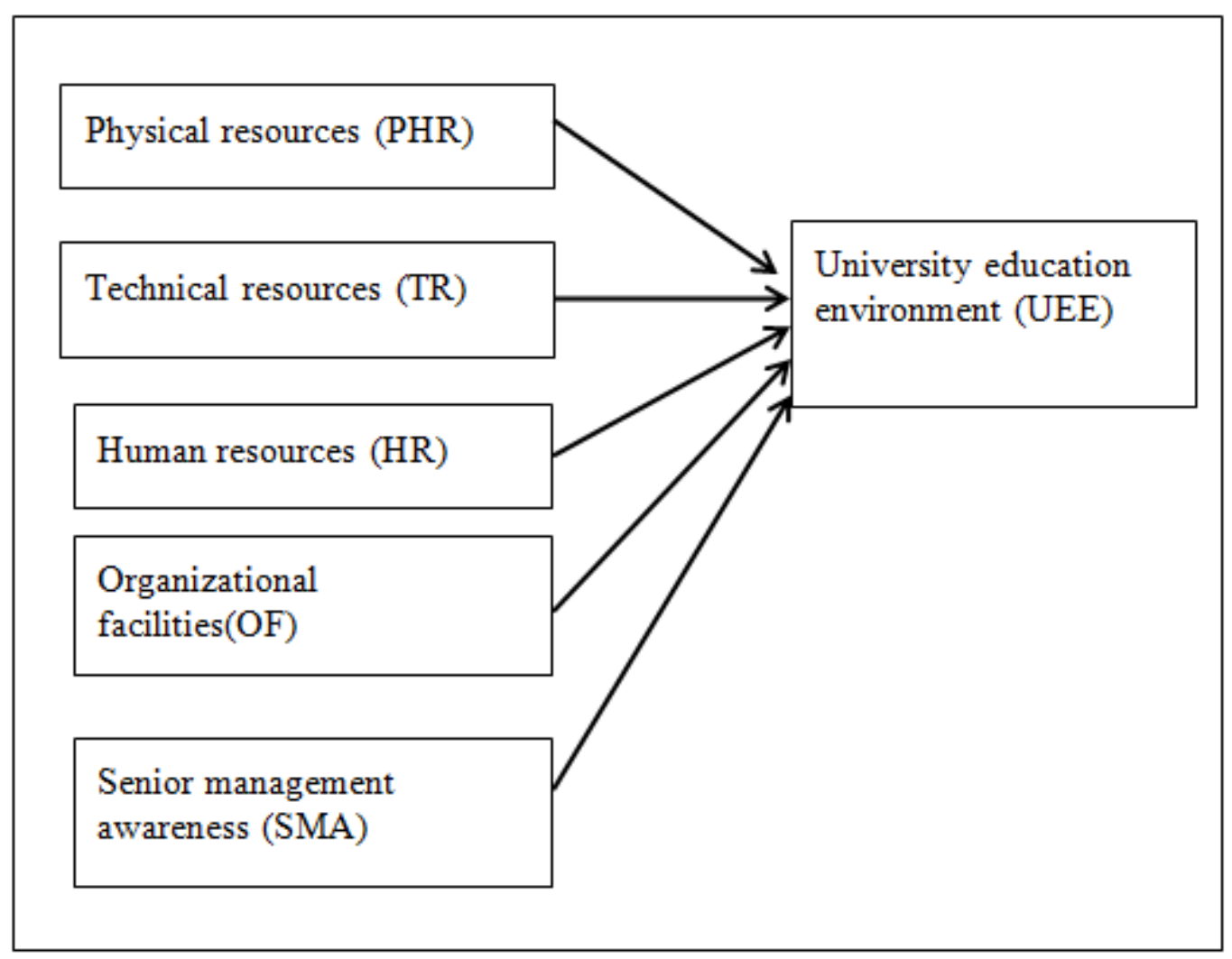

Figure 1 Research module (Mabrouk, 2012). 


\section{METHODOLOGY}

Our survey population consisted of faculty members of Taibah University. A regular random sample was used, in which 131 respondents were identified. The questionnaire was divided into five parts: part 1, containing eight questions on demographic information; part 2, containing 12 items to measure aspects of the organization (OR); part 3, containing nine items to measure aspects pertaining to management (MA); part 4, containing 16 items to measure aspects pertaining to technology (TECH). All factors were measured using a five-point Likert scale: (1) Strongly Disagree, (2) Disagree, (3) Undecided, (4) Agree, (5) Strongly Agree.

The current study applied Structural Equation Modeling (SEM) as to analyze the collected data instead of multiple regressions because SEM can give more goodness of fit indices for the full structural model, giving more superior empirical results (Hair, Black, Babin, \& Anderson, 2010).

\section{DATA COLLECTION AND ANALYSIS}

The survey questionnaires were available online and 131 responses were collected. Demographic information for the study sample is presented in Table 1.

Table 1 Participant Demographic Information

\begin{tabular}{llcc}
\hline Demographic profile & \multicolumn{1}{c}{ Group } & Number & Percentage \\
\hline \multirow{2}{*}{ Sex } & Male & 94 & $72 \%$ \\
& Female & 37 & $28 \%$ \\
Age & Less than 40 & 46 & $35 \%$ \\
& 40 or more & 84 & $65 \%$ \\
& Professor & 5 & $4 \%$ \\
Qualification & Associate professor & 24 & $18 \%$ \\
& Assistant professor & 73 & $56 \%$ \\
& Lecturer & 24 & $18 \%$ \\
& Teaching assistant & 1 & $0.8 \%$ \\
\multirow{3}{*}{ Years of experience } & 4 & $3.2 \%$ \\
& Administrative & 81 & $63.3 \%$ \\
& Seven years or more & 37 & $28.9 \%$ \\
& 3-7 & 5 & $3.9 \%$ \\
\hline
\end{tabular}

The majority of respondents were over 40 years old, with more male than female respondents (see Table 1). Almost two-thirds of the respondents were assistant professors and associate professors. Finally, most respondents had greater than seven years experience.

\section{RELIABILITY AND VALIDITY ANALYSIS}

For each of the five variables in this study, SPSS 22.0 was used to find Cronbach's alpha and AMOS to find correlation values. According to Nunnally and Bernstein (1994), to be acceptable, each variable must show Cronbach's alpha values above 0.60 and correlations above 0.5. In the current study, these conditions are met for all variables (see Figures 2 and 3). 
The Reality of Applying Decision Support System Success Factors in the University Education Environment: Case Study Applied to Taibah University

PHR Reliability Test:

Reliability Statistics

\begin{tabular}{|l|l|}
\hline $\begin{array}{l}\text { Cronbach's } \\
\text { Alpha }\end{array}$ & N of Items \\
\hline 0.859 & 12 \\
\hline
\end{tabular}

TR Reliability Test:

Reliability Statistics

\begin{tabular}{|l|l|}
\hline $\begin{array}{l}\text { Cronbach's } \\
\text { Alpha }\end{array}$ & N of Items \\
\hline 0.911 & 8 \\
\hline
\end{tabular}

HR Reliability Test:

Reliability Statistics

\begin{tabular}{|l|l|}
\hline $\begin{array}{l}\text { Cronbach's } \\
\text { Alpha }\end{array}$ & N of Items \\
\hline 0.928 & 7 \\
\hline
\end{tabular}

Figure 2 Cronbach's alpha results (from SPSS).

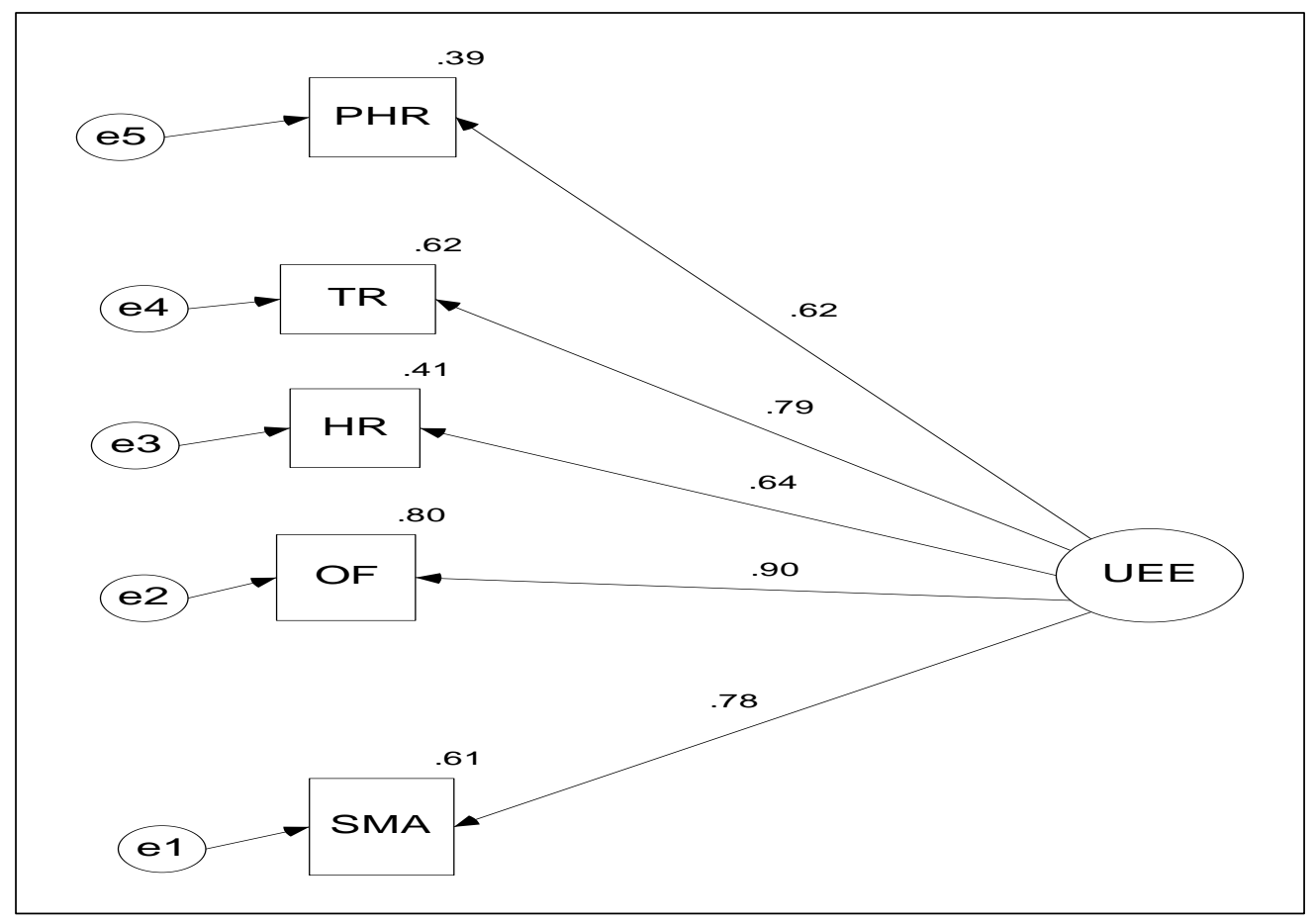

Figure 3 Correlation value results (from AMOS).

Cronbach's alpha and correlation values for all items are presented in Table 2. It can be seen that the correlations are above 0.5 and all Cronbach's alphas are above 0.9. Therefore, the variables have an acceptable level of reliability(Nunnally \& Bernstein, 1994). 
Dr. Ahmad Abdelqader Abuseeni and Dr. Husam Alfahl

Table 2 Results of Reliability Analysis

\begin{tabular}{cccc}
\hline Variable & Cronbach's Alpha & \# of Items & Correlation Values \\
\hline Total & 0.967 & 44 & \\
PHR & 0.859 & 12 & 0.60 \\
TR & 0.911 & 8 & 0.75 \\
HR & 0.928 & 7 & 0.80 \\
OF & 0.938 & 9 & 0.79 \\
SMA & 0.941 & 8 & 0.82 \\
\hline
\end{tabular}

\section{CONVERGENT VALIDITY ANALYSIS}

The investigation of the validity was accomplished using confirmatory factor analysis (CFA). Moreover, the average variance extracted (AVE) and combination validity (CR) were calculated manually by following the steps mentioned by (Hair et al., 2010). The results of convergent validity analysis are presented the in Table 3. As shown in table 3, the AVE is more than 0.5 and the CR is above 0.6 for all the constructs which is acceptable (Hair et al., 2010).

Table 3 Convergent Validity Analysis

\begin{tabular}{|c|c|c|c|c|}
\hline Construct & Items & Factor loading & AVE & CR \\
\hline \multirow{12}{*}{ PHR } & PHR12 & 0.54 & \multirow{12}{*}{0.44} & \multirow{12}{*}{0.837} \\
\hline & PHR11 & 0.71 & & \\
\hline & PHR10 & 0.73 & & \\
\hline & PHR9 & -0.35 & & \\
\hline & PHR8 & 0.71 & & \\
\hline & PHR7 & 0.68 & & \\
\hline & PHR6 & 0.77 & & \\
\hline & PHR5 & 0.68 & & \\
\hline & PHR4 & 0.73 & & \\
\hline & PHR3 & 0.58 & & \\
\hline & PHR2 & 0.65 & & \\
\hline & PHR1 & 0.72 & & \\
\hline \multirow{8}{*}{ TR } & TR8 & 0.71 & \multirow{8}{*}{0.56} & \multirow{8}{*}{0.905} \\
\hline & TR7 & 0.63 & & \\
\hline & TR6 & 0.61 & & \\
\hline & TR5 & 0.79 & & \\
\hline & TR4 & 0.79 & & \\
\hline & TR3 & 0.80 & & \\
\hline & TR2 & 0.84 & & \\
\hline & TR1 & 0.80 & & \\
\hline \multirow{7}{*}{ HR } & HR7 & 0.80 & \multirow{7}{*}{0.65} & \multirow{7}{*}{0.907} \\
\hline & HR6 & 0.60 & & \\
\hline & HR5 & 0.76 & & \\
\hline & HR4 & 0.87 & & \\
\hline & HR3 & 0.90 & & \\
\hline & HR2 & 0.86 & & \\
\hline & HR1 & 0.83 & & \\
\hline \multirow{2}{*}{ OF } & OF9 & 0.77 & \multirow{2}{*}{0.63} & \multirow{2}{*}{0.931} \\
\hline & OF8 & 0.73 & & \\
\hline
\end{tabular}


The Reality of Applying Decision Support System Success Factors in the University Education Environment: Case Study Applied to Taibah University

\begin{tabular}{llll}
\hline & OF7 & 0.85 & \\
OF6 & 0.80 & \\
OF5 & 0.90 & \\
OF4 & 0.87 & \\
OF3 & 0.78 & 0.928 \\
OF2 & 0.71 & \\
OF1 & 0.69 & \\
SMA & 0.77 & \\
& SMA7 & 0.80 & \\
& SMA6 & 0.91 & \\
& SMA5 & 0.87 & \\
SMA4 & 0.80 & \\
SMA3 & 0.84 & \\
\hline
\end{tabular}

As can be seen in Table 3, AVE and CR for all constructs meet the standards, except for items PHR9and PHR3, which have factor loadings of -0.347 and 0.58 respectively, which render the value of AVG for the variable PHR to be less than the allowable standard $(0.44<0.5)$. This did not appear through Cronbach's alpha and correlation value analysis, underscoring the importance of the convergent validity analysis using CFA. On the basis of this result, PHR3 and PHR9 were eliminated, and the previous analysis for PHR repeated. With this change, the value of AVG became 0.50, implying the scales have acceptable convergent validity(Hair et al., 2010) (see Table 4).

Table 4 Modification Convergent Validity Analysis for PHR

\begin{tabular}{ccccc}
\hline Construct & Items & Factor loading & AVE & CR \\
\hline & PHR12 & 0.533 & & \\
& PHR11 & 0.713 & & \\
& PHR10 & 0.734 & & \\
& PHR8 & 0.707 & & \\
PHR & PHR7 & 0.687 & 0.571 \\
& PHR6 & 0.78 & & \\
& PHR5 & 0.683 & & \\
& PHR4 & 0.719 & & \\
& PHR2 & 0.633 & & \\
& PHR1 & 0.716 & & \\
\hline
\end{tabular}

\section{DISCRIMINATION VALIDITY ANALYSIS}

The square root of AVE and the correlation coefficient matrix were used to test the discrimination validity of the constructs. According to Fornell and Larcker (1981), the square root of AVE is required to be greater than its correlation coefficient with another construct.. In Table 5, the values in the diagonal line represent the square root of AVE of constructs; other data represent the correlation coefficient of the row construct and the column construct of the data. Therefore, the scale has an acceptable discrimination validity. 
Dr. Ahmad Abdelqader Abuseeni and Dr. Husam Alfahl

Table 5 Analysis Results of Discrimination Validity

\begin{tabular}{cccccc}
\hline & PHR & TR & HR & OF & SMA \\
\hline PHR & 0.7071 & & & & \\
TR & 0.6470 & 0.7483 & & & \\
HR & 0.5390 & 0.5680 & 0.8062 & & \\
OF & 0.498 & 0.6820 & 0.5490 & 0.7937 & \\
SMA & 0.379 & 0.5560 & 0.4250 & 0.7680 & 0.8185 \\
\hline
\end{tabular}

As each construct's square root of AVE is greater than its correlation coefficient with another construct, we conclude that the scales have acceptable discrimination validity.

\section{CONFIRMATORY FACTOR ANALYSIS (CFA)}

CFA is the next step following EFA in determining the factor structure of the data set; CFA is used to confirm the factor structure extracted in the previous stage (Hair et al., 2010). The CFA was conducted using AMOS for each variable. Results for the CFA of the 12 PHR items measuring organization(OR) are shown in Figure 4.

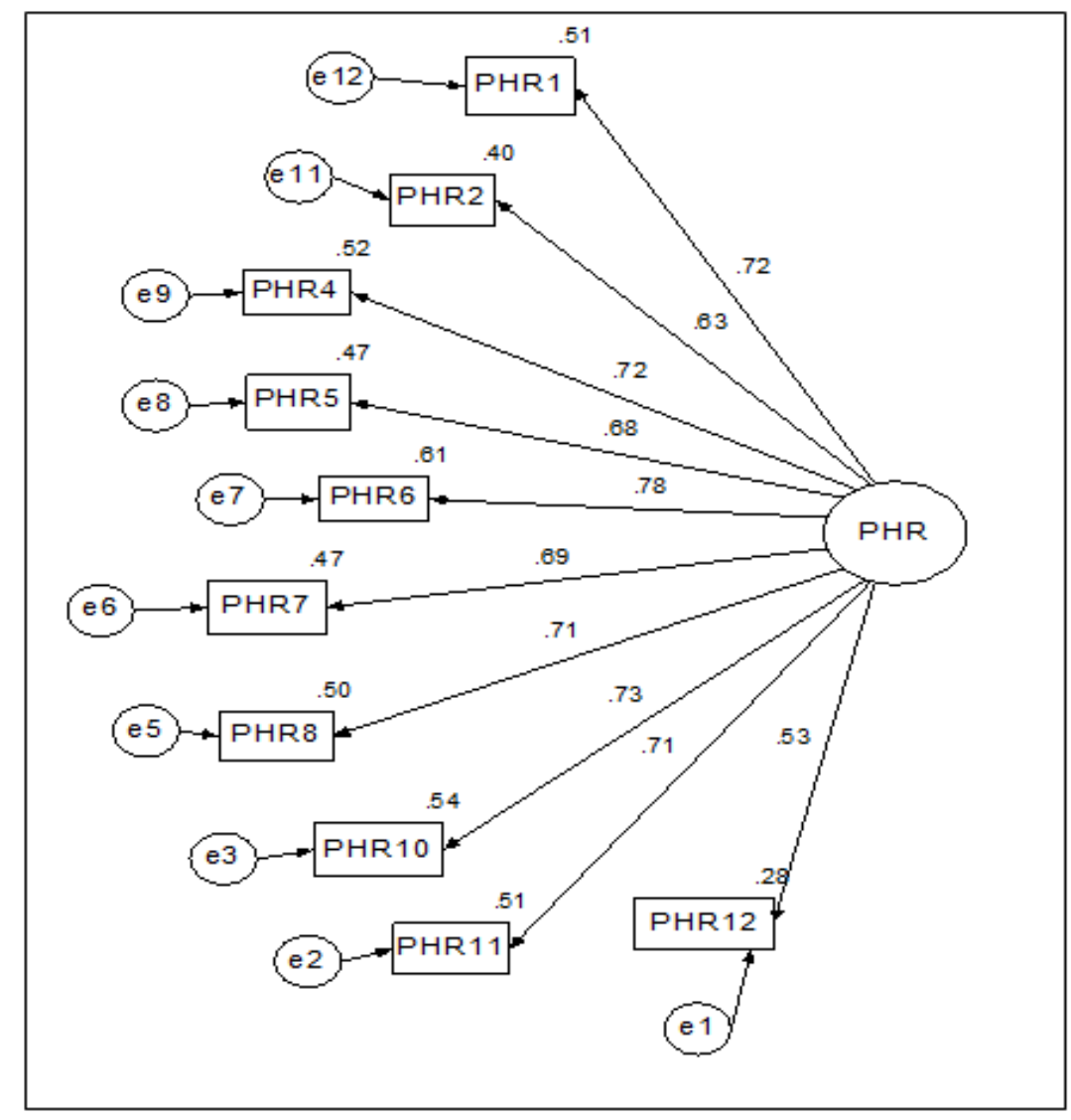

Figure 4 PHR CFA.

According to Hair et al. (2010), the standardized loading estimates should be 0.5 or higher. As the values for the PHR item loading factors lie in the range $0.53-0.78$, we conclude that PHR has an acceptable factor loading (see Figure 4).

The same steps were done for TR CFA, CFA OF, HR CFA, SMA CFA, the details was illustrated in the appendix., as the items loading factor values lie in the range 0.50-0.90, we conclude that it have an acceptable factor loading(Hair et al., 2010). 
The Reality of Applying Decision Support System Success Factors in the University Education Environment: Case Study Applied to Taibah University

\section{FREQUENT DISCUSSIONS}

An estimated Likert scale balance was calculated by dividing the scale into equal ranges; that is, calculating the range $=5-1=4$, then dividing by 5 ,to give 0.80 as shown in table 6 .

Table 6 Likert Scale Balance

\begin{tabular}{lcc}
\hline \multicolumn{1}{c}{ Response } & Mean & General trend \\
\hline Strongly disagree & $1-1.80$ & Strongly disagree \\
Disagree & $1.81-2.60$ & Disagree \\
Quite true & $2.61-3.40$ & Quite true \\
Agree & $3.41-4.20$ & Agree \\
Strongly agree & 4.21 or more & Strongly agree \\
\hline
\end{tabular}

Table 7 Results for Physical Resources (PHR)

\begin{tabular}{|c|c|c|c|c|c|c|c|c|}
\hline Item & 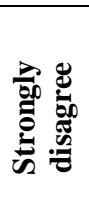 & 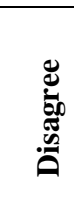 & 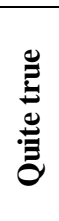 & 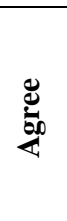 & 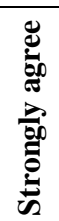 & Mean & Std. Deviation & $\begin{array}{l}\text { The general } \\
\text { trend }\end{array}$ \\
\hline $\begin{array}{l}\text { PHR1 } \\
\text { Number of computer devices suitable for } \\
\text { the number of employees in the } \\
\text { department }\end{array}$ & 34 & 18 & 20 & 33 & 26 & 2.99 & 1.49 & Quite true \\
\hline $\begin{array}{l}\text { PHR2 } \\
\text { Computers provide enough space to store } \\
\text { information }\end{array}$ & 17 & 17 & 30 & 39 & 28 & 3.33 & 1.30 & Quite true \\
\hline $\begin{array}{l}\text { PHR3 } \\
\text { There are default storage devices (external } \\
\text { location using the Internet) }\end{array}$ & 22 & 28 & 34 & 28 & 19 & 2.95 & 1.30 & Quite true \\
\hline $\begin{array}{l}\text { PHR } 4 \\
\text { Data entry is available to suit the business } \\
\text { needs of the department }\end{array}$ & 19 & 29 & 40 & 37 & 6 & 2.86 & 1.12 & Quite true \\
\hline $\begin{array}{l}\text { PHR5 } \\
\text { The capability of the existing network } \\
\text { iscompatiblewith the work needs of the } \\
\text { circuit }\end{array}$ & 20 & 24 & 39 & 41 & 7 & 2.93 & 1.15 & Quite true \\
\hline $\begin{array}{l}\text { PHR6 } \\
\text { The output devices are compatible with the } \\
\text { work requirements of the circuit }\end{array}$ & 12 & 32 & 52 & 31 & 4 & 2.87 & 0.98 & Quite true \\
\hline $\begin{array}{l}\text { PHR7 } \\
\text { The speed of computers is compatible with } \\
\text { the volume of work required to be } \\
\text { completed }\end{array}$ & 12 & 41 & 39 & 30 & 9 & 2.87 & 1.08 & Quite true \\
\hline $\begin{array}{l}\text { PHR8 } \\
\text { The speed of connection is appropriate }\end{array}$ & 17 & 43 & 34 & 31 & 6 & 2.74 & 1.09 & Quite true \\
\hline $\begin{array}{l}\text { PHR9 } \\
\text { Frequent interruptions occur in the } \\
\text { network used }\end{array}$ & 8 & 22 & 38 & 34 & 35 & 3.50 & 1.22 & Agree \\
\hline $\begin{array}{l}\text { PHR10 } \\
\text { The network malfunction is processed } \\
\text { quickly }\end{array}$ & 22 & 32 & 44 & 25 & 8 & 2.73 & 1.14 & Quite true \\
\hline $\begin{array}{l}\text { PHR11 } \\
\text { When computer devices fail, maintenance } \\
\text { is quick }\end{array}$ & 20 & 34 & 49 & 22 & 6 & 1.69 & 1.07 & Quite true \\
\hline $\begin{array}{l}\text { PHR12 } \\
\text { Information technology (network and } \\
\text { related devices) is updated periodically }\end{array}$ & 26 & 34 & 41 & 25 & 5 & 2.61 & 1.12 & Quite true \\
\hline
\end{tabular}


The general trend of the responses for PHR (calculating averages, frequencies, percentages and standard deviations) was 'Quite True'; this held for all items except PHR9. This result implies some difficulties in providing:

- A suitable number of computer devices.

- Enough space to store information.

- A default storage device (external location using the Internet).

- Data entry that suits the business needs of the department.

- A network with appropriate capabilities.

- Output devices compatible with the work requirements.

- Computer speed compatible with the volume of work required.

- Adequate speed of connection.

- Processes to adequately resolve network malfunctions.

- Well-maintained computerized devices.

- Updated information technology (network and related devices).

The result for PHR9 was 'Agree', which implies that frequent interruptions occur in the network.

Note that in applying CFA, weeliminatedPHR3 and PHR9, so results are not included in the final recommendations.

The same steps were done for (TR), (HR), (OF), (SMA), the details was illustrated in the appendix.

After calculating averages, frequencies, percentages and standard deviations, the general trend of responses regarding senior management awareness was 'Quite True' (see Table 11). This implies some difficulties regarding:

- Senior managers' conviction in regards to DSS.

- Senior managers' encouragement of staff to use DSS.

- Senior managers' support of training courses in DSS.

- Senior managers' provision of hardware and software required to use DSS.

- Senior managers' support for staff efforts to design and develop DSS.

- Senior managers' concern for making the process of design and development of DSS part of the overall comprehensive organizational development procedures.

- The stimulation of employees who rely on DSS.

- Senior managers' awareness of the importance of DSS.

\section{DISCUSSION AND CONCLUSION}

In summary, regarding the first factor, physical resources(PHR), the general trend of responses indicates a need to provide:

- A suitable number of computer devices.

- Enough space to store information.

- A default storage device (external location using the Internet).

- Data entry that suits the business needs of the department.

- A network with appropriate capabilities.

- Output devices compatible with the work requirements.

- Computer speed compatible with the volume of work required.

- Adequate speed of connection. 
The Reality of Applying Decision Support System Success Factors in the University Education Environment: Case Study Applied to Taibah University

- Processes to adequately resolve network malfunctions.

- Well-maintained computerized devices.

- Updated information technology (network and related devices).

The result for PHR9 was 'Agree', which implies that frequent interruptions occur in the network.

Note that in applying CFA, we eliminated PHR3 and PHR9, so results are not included in the final recommendations.

Regarding the second factor, technical resources(TR), the general trend of responses indicates a need to provide:

- Software services (updated procedures and users' guide).

- Software compatible with work requirements.

- Software compatible with the devices being used.

- Software compatible with the network used.

- Software compatible with the activities of the department.

- The possibility of evaluation by the user.

- Database availability.

- Instructions needed to run the programs.

Regarding the third factor, $\mathrm{HR}$, the general trend of responses indicates a need to provide:

- Qualified technical department staff.

- Experienced technical department staff.

- Technical department staff who respond quickly to employees' inquiries.

- Procedures for repairing faults.

- Processes for efficient communication with the technical department.

- Technical staff with good communication skills.

- Technical staff well able to understand and handle the needs of users.

Regarding the fourth factor, organizational facilities (OF), the general trend of responses indicates a need to provide:

- Adequate information.

- Accessible information.

- Financial support for the use of DSS.

- Training plans for employees to use DSS.

- The usage of DSS to follow up on workflow.

- Procedures for dealing with development suggestions by users.

- Requirements for the organization to better use DSS.

- Procedures for evaluating performance by users.

- Good flow of information through the organizational structure.

Regarding the fifth factor, senior management awareness(SMA), the general trend of responses indicates a need to improve:

- Senior managers' conviction in regards to DSS.

- Senior managers' encouragement of staff to use DSS.

- Senior managers' support of training courses in DSS. 
- Senior managers' provision of hardware and software required to use DSS.

- Senior managers' support for staff efforts to design and develop DSS.

- Senior managers' concern for making the process of design and development of DSS part of the overall comprehensive organizational development procedures.

- The stimulation of employees who rely on DSS.

- Senior managers' awareness of the importance of DSS.

By highlighting the reality of applying the success factors of design support systems in the university education environment, the results indicate that there is a need to develop some elements supporting these factors. According to respondents' recommendations, the technical resources(TR) and senior management awareness (SMA) captured a great deal of concentration and attention so we can say it is the most influential factors, this is consistent with previous studies discussed in the literature review. It is hoped that this will contribute in the development and the improvement of the university education environment.

\section{REFERENCES}

[1] Al-Mobaideen, H., Allahawiah, S., \& Basioni, B. (2013). Factors influencing the successful adoption of human resource information system: The content of Aqaba Special Economic Zone Authority. Intelligent Information Management, 5, 1-9.

[2] Al Hassani, A. (2013). The Impact between Decision Support Systems , Information Quality and Effective Decision-Making: A field study on Ministry of Civil Service Sultanate of Oman. (Master), Middle East University, Oman.

[3] Brockbank, W. (1999). If HR were really strategically proactive: Present and future directions in HR's contribution to competitive advantage. Human Resource Management, 38(4), 337-352.

[4] DeSanctis, G. (1986). Human resource information systems-A current assessment. MIS Quarterly, 10(1), 15-27.

[5] Fornell, C., \& Larcker, D. F. (1981). Evaluating structural equation models with unobservable variables and measurement error. Journal of marketing research, 18, 39-50.

[6] Guimares, T., Igbaria, M., \& Lu, M. (1992). The determinants of DSS success: An integrated model. Decision Sciences, 23, 409-430.

[7] Hair, J., Black, W., Babin, B., \& Anderson, R. (2010). Multivariate Data Analysis. Upper Saddle River, New Jersey.: Prentice Hall.

[8] Hitt, M., Wu, J., \& Zhou, X. (2002). Investment in enterprise resource planning: Business impact and productivity measures. Journal of Management Information Systems, 19(1), 71-98.

[9] Mabrouk, A. I. (2012). Information and its role in support and strategic decision-making (1st ed.). Cairo: Arab Group for Training and Publishing.

[10] Nunnally, J., \& Bernstein, I. (1994). Psychometric Theory (3rd ed.). New York: McGrawHill. .

[11] Ramadan, F. (2009). The impact of decision support systems on developing the performance of the ministry of education. (Master), Islamic University, Gaza.

[12] Sanders, G. L., \& Courtney, J. F. (1985). A field study of organizational factors influencing DSS success. MIS Quarterly, 9(1), 77-93.

\section{APPENDIX 1}

\section{Confirmatory Factor Analysis (CFA)}

CFA is the next step following EFA in determining the factor structure of the data set; CFA is used to confirm the factor structure extracted in the previous stage (Hair et al., 2010). The CFA was conducted using AMOS for each variable. Results for the CFA of the 12 PHR items measuring organization (OR) are shown in Figure 1. 
The Reality of Applying Decision Support System Success Factors in the University Education Environment: Case Study Applied to Taibah University

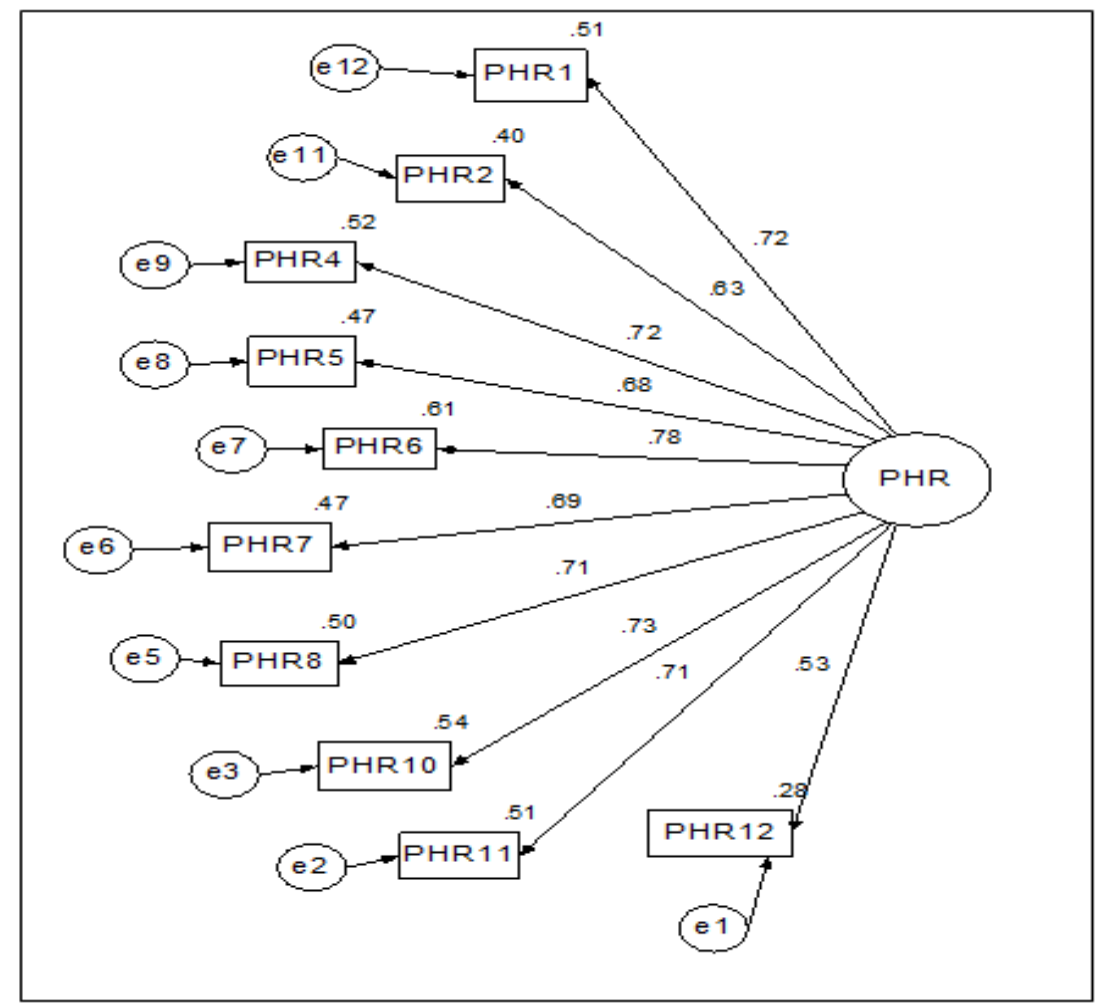

Figure 1 PHR CFA.

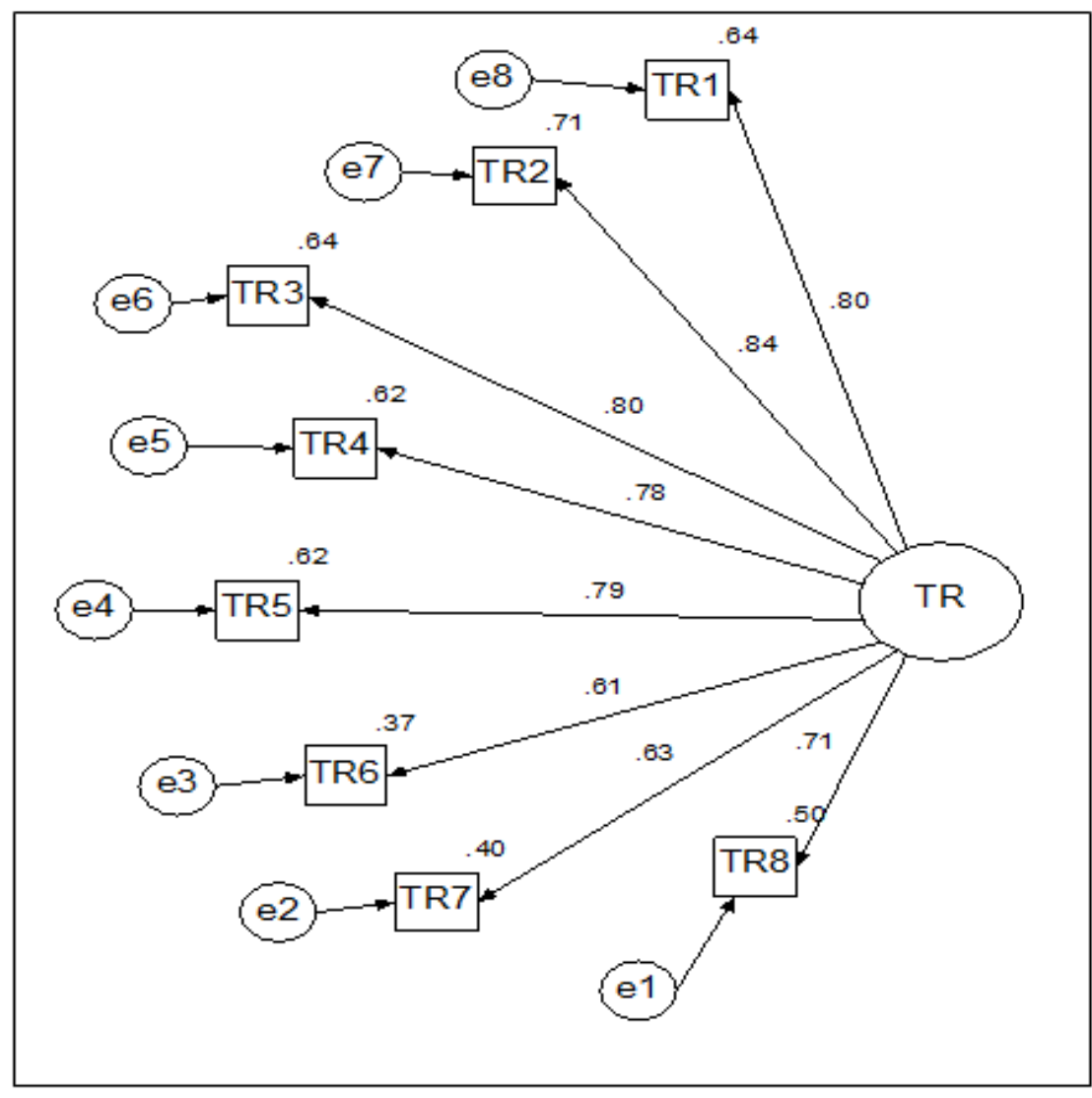

Figure 2 TR CFA. 
HR contains seven items. Values for all loading factors for these HR items lie in the range 0.60-0.90, implying that HR has an acceptable factor loading (Hair et al., 2010).

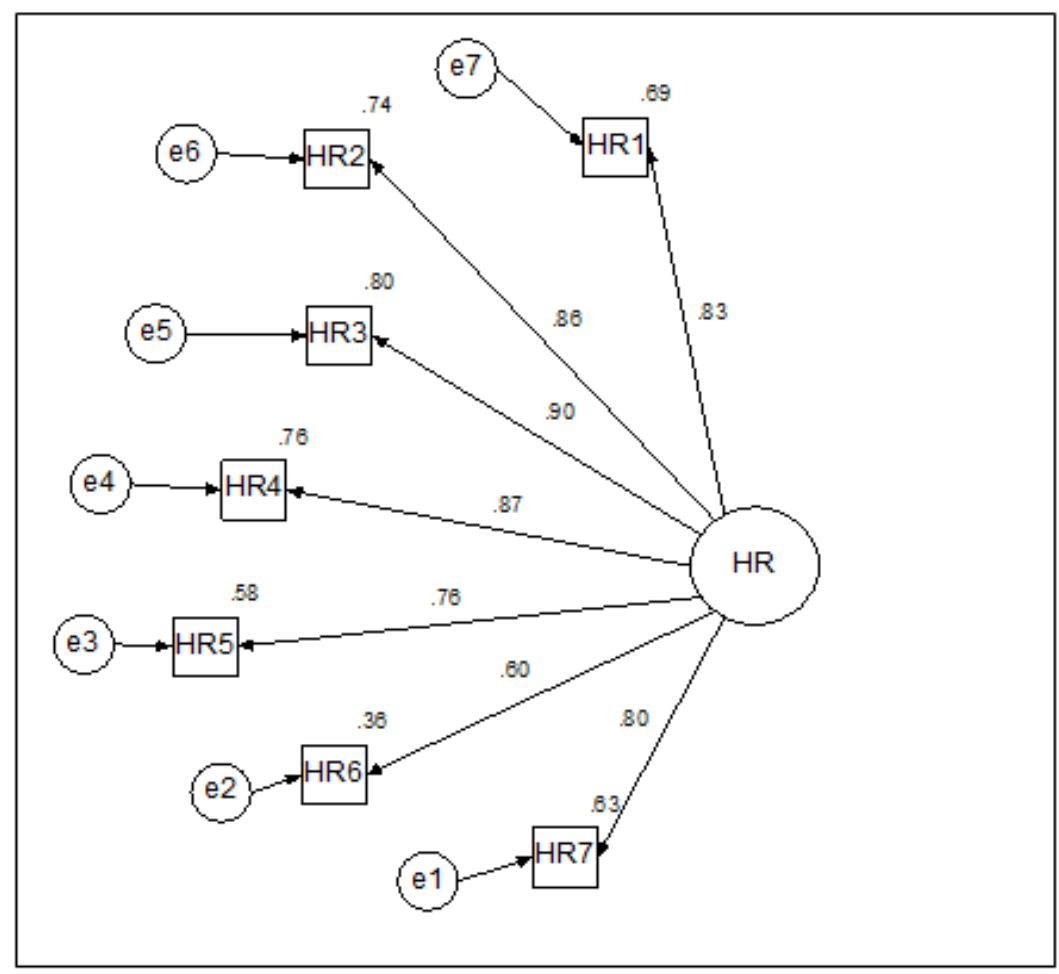

Figure 3 HR CFA.

OF contains nine items. In the CFA OF, the loading factor values were in the range 0.690.90, implying an acceptable factor loading (see Figure 4)(Hair et al., 2010).

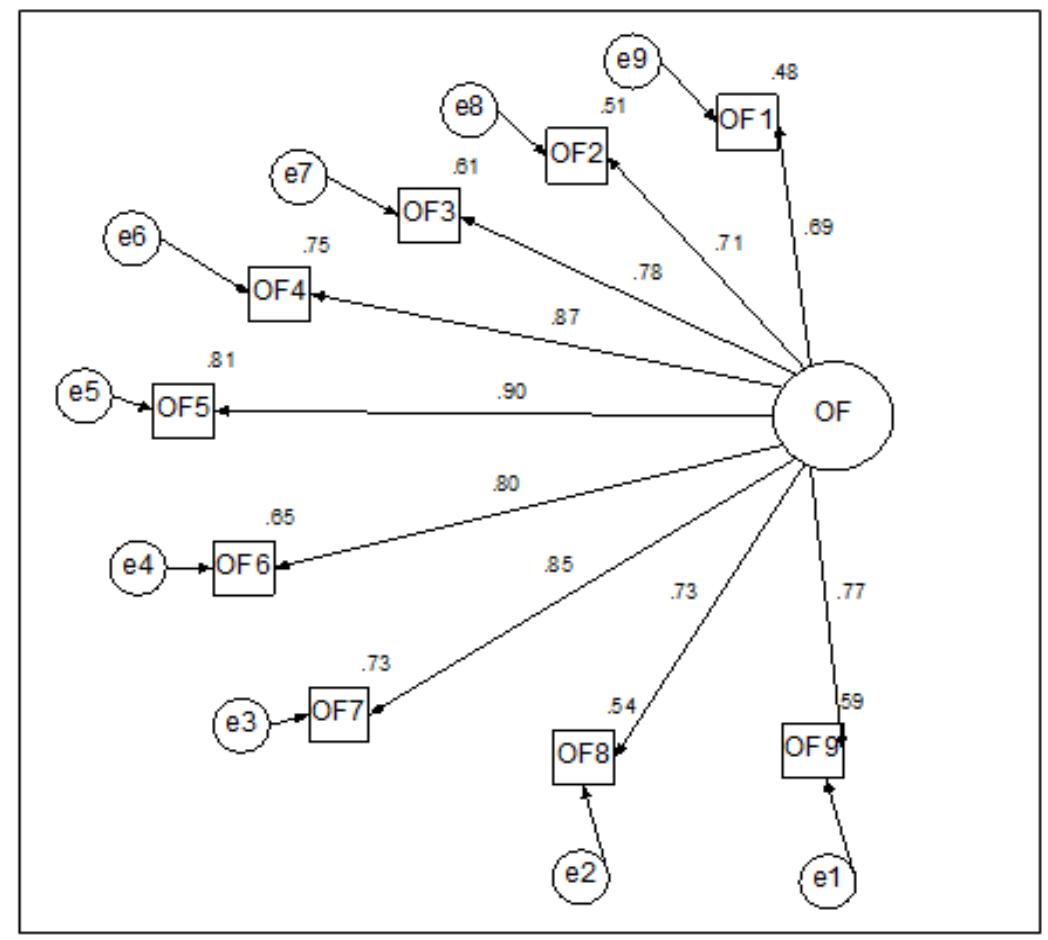

Figure 4 OF CFA. 
The Reality of Applying Decision Support System Success Factors in the University Education Environment: Case Study Applied to Taibah University

SMA includes eight items. As shown in Figure 8, the SMA items' loading factor values were in the range 0.74-0.90, implying an acceptable factor loading (Hair et al., 2010).

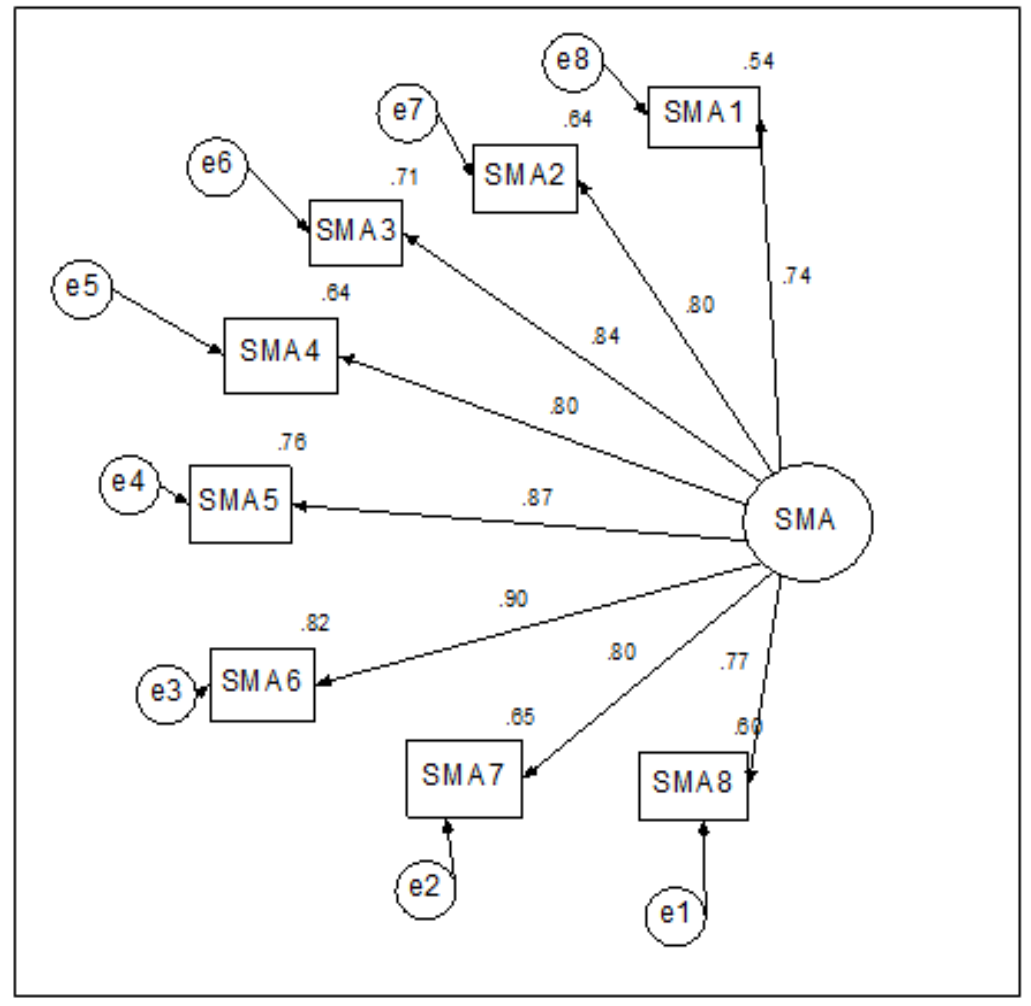

Figure 5 SMA CFA.

\section{FREQUENT DISCUSSIONS}

An estimated Likert scale balance was calculated by dividing the scale into equal ranges; that is, calculating the range $=5-1=4$, then dividing by 5 , to give 0.80 (Table 1$)$.

Table 1 Likert Scale Balance

\begin{tabular}{lcc}
\hline \multicolumn{1}{c}{ Response } & Mean & General trend \\
\hline Strongly disagree & $1-1.80$ & Strongly disagree \\
Disagree & $1.81-2.60$ & Disagree \\
Quite true & $2.61-3.40$ & Quite true \\
Agree & $3.41-4.20$ & Agree \\
Strongly agree & 4.21 or more & Strongly agree \\
\hline
\end{tabular}

Table 7 Results for Physical Resources(PHR)

\begin{tabular}{|c|c|c|c|c|c|c|c|c|}
\hline Item & 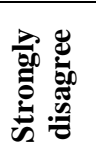 & 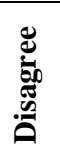 & : & 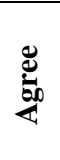 & 常 & Mean & Std. Deviation & $\begin{array}{l}\text { The general } \\
\text { trend }\end{array}$ \\
\hline $\begin{array}{l}\text { PHR1 } \\
\text { Number of computer devices suitable for the } \\
\text { number of employees in the department }\end{array}$ & 34 & 18 & 20 & 33 & 26 & 2.99 & 1.49 & Quite true \\
\hline $\begin{array}{l}\text { PHR2 } \\
\text { Computers provide enough space to store } \\
\text { information }\end{array}$ & 17 & 17 & 30 & 39 & 28 & 3.33 & 1.30 & Quite true \\
\hline $\begin{array}{l}\text { PHR3 } \\
\text { There are default storage devices (external } \\
\text { location using the Internet) }\end{array}$ & 22 & 28 & 34 & 28 & 19 & 2.95 & 1.30 & Quite true \\
\hline
\end{tabular}


Dr. Ahmad Abdelqader Abuseeni and Dr. Husam Alfahl

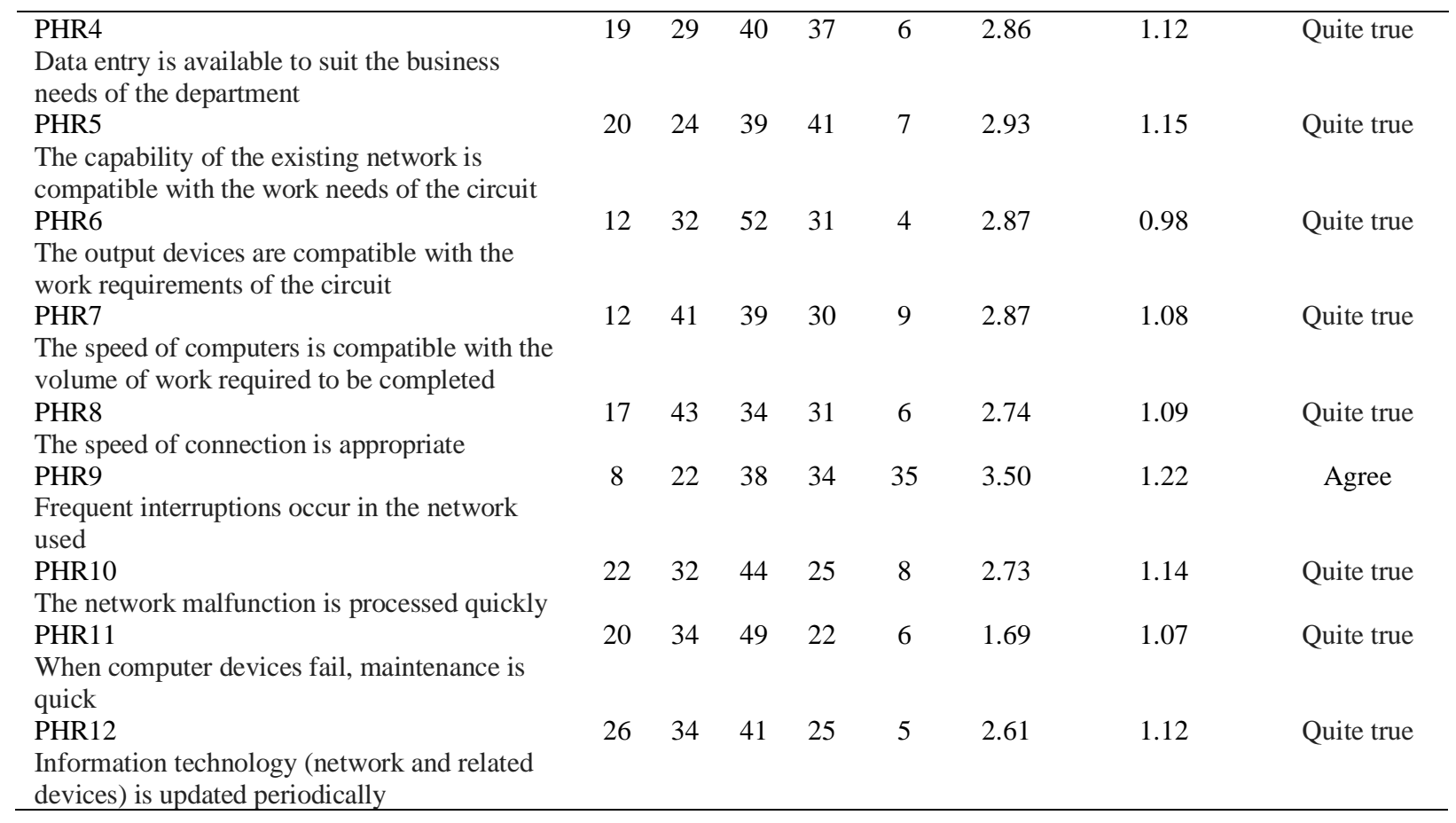

The general trend of the responses for PHR (calculating averages, frequencies, percentages and standard deviations) was 'Quite True'; this held for all items except PHR9. This result implies some difficulties in providing:

- A suitable number of computer devices.

- Enough space to store information.

- A default storage device (external location using the Internet).

- Data entry that suits the business needs of the department.

- A network with appropriate capabilities.

- Output devices compatible with the work requirements.

- Computer speed compatible with the volume of work required.

- Adequate speed of connection.

- Processes to adequately resolve network malfunctions.

- Well-maintained computerized devices.

- Updated information technology (network and related devices).

The result for PHR9 was 'Agree', which implies that frequent interruptions occur in the network.

Note that in applying CFA, we eliminated PHR3 and PHR9, so results are not included in the final recommendations. 
The Reality of Applying Decision Support System Success Factors in the University Education Environment: Case Study Applied to Taibah University

Table 2 Results for Technical Resources (TR)

\begin{tabular}{|c|c|c|c|c|c|c|c|c|}
\hline Item & 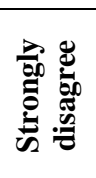 & 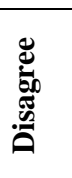 & 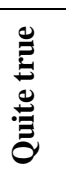 & 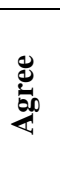 & 或 & Mean & Std. Deviation & $\begin{array}{l}\text { The } \\
\text { general } \\
\text { trend }\end{array}$ \\
\hline $\begin{array}{l}\text { TR1 } \\
\text { The software used is updated and } \\
\text { easy to learn }\end{array}$ & 9 & 33 & 39 & 41 & 9 & 3.06 & 1.05 & Quite true \\
\hline $\begin{array}{l}\text { TR2 } \\
\text { The software used is compatible with } \\
\text { the work requirements of the } \\
\text { department }\end{array}$ & 12 & 25 & 44 & 44 & 6 & 3.05 & 1.04 & Quite true \\
\hline $\begin{array}{l}\text { TR3 } \\
\text { The software used is compatible with } \\
\text { the devices being used }\end{array}$ & 14 & 23 & 38 & 52 & 4 & 3.06 & 1.06 & Quite true \\
\hline $\begin{array}{l}\text { TR4 } \\
\text { The software is compatible with the } \\
\text { network }\end{array}$ & 9 & 27 & 45 & 48 & 2 & 3.05 & 0.96 & Quite true \\
\hline $\begin{array}{l}\text { TR5 } \\
\text { The software available cover all the } \\
\text { activities of the department }\end{array}$ & 14 & 38 & 46 & 28 & 5 & 2.79 & 1.02 & Quite true \\
\hline $\begin{array}{l}\text { TR6 } \\
\text { Software effectiveness can be } \\
\text { evaluated by users }\end{array}$ & 22 & 44 & 43 & 19 & 3 & 2.52 & 1.01 & Quite true \\
\hline $\begin{array}{l}\text { TR7 } \\
\text { A database is available to assist in the } \\
\text { progress of performance }\end{array}$ & 23 & 39 & 39 & 26 & 4 & 2.61 & 1.08 & Quite true \\
\hline $\begin{array}{l}\text { TR8 } \\
\text { All instructions are available to run } \\
\text { the programs needed at work }\end{array}$ & 15 & 43 & 42 & 27 & 4 & 2.70 & 1.01 & Quite true \\
\hline
\end{tabular}

For technical resources, the general trend of the responses was 'Quite True', indicating some difficulties in providing:

- Software services (updated procedures and users' guide).

- Software compatible with work requirements.

- Software compatible with the devices being used.

- Software compatible with the network used.

- Software compatible with the activities of the department.

- The possibility of evaluation by the user.

- Database availability.

- Instructions needed to run the programs.

Table 3 shows the responses for the items pertaining to extent of support.

Table 3 Results for Human Resources (HR)

\begin{tabular}{|c|c|c|c|c|c|c|c|c|}
\hline Item & 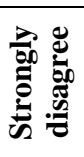 & 总 & 莺 & 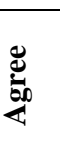 & 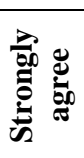 & Mean & $\begin{array}{c}\text { Std. } \\
\text { Deviation }\end{array}$ & $\begin{array}{l}\text { The } \\
\text { general } \\
\text { trend }\end{array}$ \\
\hline $\begin{array}{l}\text { HR1 } \\
\text { The technical department is } \\
\text { staffed by IT specialists }\end{array}$ & 19 & 30 & 35 & 38 & 9 & 2.90 & 1.17 & Quite true \\
\hline $\begin{array}{l}\text { HR2 } \\
\text { There are highly qualified staff in } \\
\text { the technical department }\end{array}$ & 19 & 29 & 46 & 32 & 5 & 2.81 & 1.08 & Quite true \\
\hline
\end{tabular}


Dr. Ahmad Abdelqader Abuseeni and Dr. Husam Alfahl

\begin{tabular}{|c|c|c|c|c|c|c|c|c|}
\hline $\begin{array}{l}\text { HR3 } \\
\text { The technical department } \\
\text { responds quickly to employees' } \\
\text { inquiries }\end{array}$ & 23 & 27 & 39 & 37 & 5 & 2.81 & 1.15 & Quite true \\
\hline $\begin{array}{l}\text { HR4 } \\
\text { The relevant technical section } \\
\text { fixes the problems faced by } \\
\text { network and software users } \\
\text { quickly }\end{array}$ & 16 & 25 & 44 & 40 & 6 & 2.96 & 1.08 & Quite true \\
\hline $\begin{array}{l}\text { HR5 } \\
\text { There is direct contact with the } \\
\text { technical department }\end{array}$ & 10 & 28 & 31 & 50 & 12 & 3.20 & 1.11 & Quite true \\
\hline $\begin{array}{l}\text { HR6 } \\
\text { I have good relations with the } \\
\text { technical staff responsible for the } \\
\text { systems }\end{array}$ & 8 & 20 & 41 & 43 & 19 & 3.34 & 1.09 & Quite true \\
\hline $\begin{array}{l}\text { HR7 } \\
\text { Employees in the technical } \\
\text { department understand the needs } \\
\text { of employees }\end{array}$ & 13 & 20 & 38 & 47 & 13 & 3.20 & 1.13 & Quite true \\
\hline
\end{tabular}

The general trend of the responses pertaining to HR was 'Quite True', implying some difficulties in providing:

- Qualified technical department staff.

- Experienced technical department staff.

- Technical department staff who respond quickly to employees' inquiries.

- Procedures for repairing faults.

- Processes for efficient communication with the technical department.

- Technical staff with good communication skills.

- Technical staff well able to understand and handle the needs of users.

Table 4 Results for Organizational Facilities (OF)

\begin{tabular}{|c|c|c|c|c|c|c|c|c|}
\hline Item & 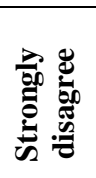 & 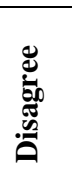 & 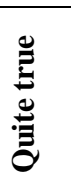 & 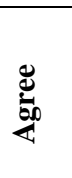 & 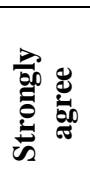 & Mean & $\begin{array}{c}\text { Std. } \\
\text { Deviation }\end{array}$ & $\begin{array}{l}\text { The } \\
\text { general } \\
\text { trend }\end{array}$ \\
\hline $\begin{array}{l}\text { OF1 } \\
\text { The information available from } \\
\text { the support systems is } \\
\text { commensurate with the needs of } \\
\text { the work }\end{array}$ & 7 & 33 & 55 & 31 & 5 & 2.95 & 0.93 & Quite true \\
\hline $\begin{array}{l}\text { OF2 } \\
\text { The information available to } \\
\text { senior management can easily be } \\
\text { obtained from my work }\end{array}$ & 17 & 41 & 40 & 27 & 6 & 2.73 & 1.07 & Quite true \\
\hline $\begin{array}{l}\text { OF3 } \\
\text { The department provides financial } \\
\text { support for the use of DSS }\end{array}$ & 27 & 43 & 40 & 18 & 3 & 2.44 & 1.03 & Quite true \\
\hline $\begin{array}{l}\text { OF4 } \\
\text { The organization follows up the } \\
\text { workflow based on DSS }\end{array}$ & 19 & 32 & 48 & 27 & 5 & 2.74 & 1.06 & Quite true \\
\hline $\begin{array}{l}\text { OF5 } \\
\text { The organization is concerned } \\
\text { with the views and suggestions of } \\
\text { staff }\end{array}$ & 22 & 37 & 40 & 35 & 7 & 2.67 & 1.12 & Quite true \\
\hline $\begin{array}{l}\text { OF6 } \\
\text { The organization provides training } \\
\text { programs on the use of DSS }\end{array}$ & 17 & 45 & 40 & 25 & 4 & 2.64 & 1.02 & Quite true \\
\hline $\begin{array}{l}\text { OF7 } \\
\text { The organization provides }\end{array}$ & 19 & 40 & 39 & 29 & 4 & 2.68 & 1.06 & Quite true \\
\hline
\end{tabular}


The Reality of Applying Decision Support System Success Factors in the University Education Environment: Case Study Applied to Taibah University

requirements for better use of

DSS

OF8

The organizational structure

makes it easy for the user to

evaluate performance

OF9

The organizational structure

allows information to flow easily

\begin{tabular}{llllllll}
14 & 38 & 40 & 29 & 10 & 2.87 & 1.11 & Quite true \\
17 & 30 & 44 & 30 & 10 & 2.89 & 1.13 & Quite true \\
& & & & & & & \\
\hline
\end{tabular}

The general trend of the responses on organizational facilities was 'Quite True', implying some difficulties in providing:

- Adequate information.

- Accessible information.

- Financial support for the use of DSS.

- Training plans for employees to use DSS.

- The usage of DSS to follow up on workflow.

- Procedures for dealing with development suggestions by users.

- Requirements for the organization to better use DSS.

- Procedures for evaluating performance by users.

- Good flow of information through the organizational structure.

Table 5 Results for Senior Management Awareness (SMA)

\begin{tabular}{|c|c|c|c|c|c|c|c|c|}
\hline Item & 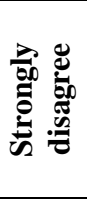 & 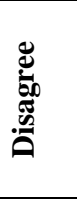 & 节 & 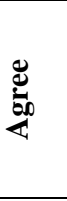 & 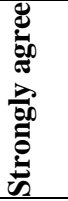 & Mean & $\begin{array}{c}\text { Std. } \\
\text { Deviation }\end{array}$ & $\begin{array}{l}\text { The } \\
\text { general } \\
\text { trend }\end{array}$ \\
\hline $\begin{array}{l}\text { SMA1 } \\
\text { Senior managers rely on DSS to make } \\
\text { decisions }\end{array}$ & 20 & 26 & 54 & 25 & 6 & 2.77 & 1.06 & Quite true \\
\hline $\begin{array}{l}\text { SMA2 } \\
\text { Senior managers encourage staff to use } \\
\text { DSS }\end{array}$ & 18 & 33 & 48 & 21 & 11 & 2.80 & 1.12 & Quite true \\
\hline $\begin{array}{l}\text { SMA3 } \\
\text { Senior managers support training } \\
\text { courses in DSS }\end{array}$ & 27 & 34 & 36 & 28 & 6 & 2.63 & 1.16 & Quite true \\
\hline $\begin{array}{l}\text { SMA4 } \\
\text { Organization managers provide the } \\
\text { hardware and software required to use } \\
\text { DSS }\end{array}$ & 21 & 40 & 37 & 29 & 4 & 2.65 & 1.08 & Quite true \\
\hline $\begin{array}{l}\text { SMA5 } \\
\text { The organization supports staff efforts } \\
\text { to design and develop DSS }\end{array}$ & 21 & 38 & 41 & 26 & 5 & 2.66 & 1.08 & Quite true \\
\hline $\begin{array}{l}\text { SMA6 } \\
\text { Organization managers are concerned } \\
\text { with making the process of design and } \\
\text { development of DSS part of the } \\
\text { overall comprehensive organizational } \\
\text { development }\end{array}$ & 21 & 33 & 49 & 23 & 5 & 2.67 & 1.06 & Quite true \\
\hline $\begin{array}{l}\text { SMA } 7 \\
\text { Organization stimulates employees } \\
\text { who rely on DSS }\end{array}$ & 21 & 44 & 42 & 21 & 3 & 2.54 & 1.01 & Quite true \\
\hline $\begin{array}{l}\text { SMA8 } \\
\text { Organization managers are well aware } \\
\text { of the importance of DSS }\end{array}$ & 15 & 23 & 53 & 27 & 13 & 3.00 & 1.11 & Agree \\
\hline
\end{tabular}

